\title{
Effect of elevated ozone, carbon dioxide and their interaction on growth, biomass and water use efficiency of chickpea (Cicer arietinum L.)
}

\author{
RAM NARAYAN SINGH ${ }^{1}$, JOYDEEP MUKHERJEE ${ }^{1}$, V. K. SEHGAL ${ }^{1}$, ARTI BHATIA ${ }^{2}$, \\ P. KRISHNAN ${ }^{1}$, DEB KUMAR DAS ${ }^{1}$, VINOD KUMAR ${ }^{2}$ and RAMESH HARIT ${ }^{2}$ \\ ${ }^{1}$ Division of Agricultural Physics \\ ${ }^{2}$ Centre for Environmental Science and Climate Resilient Agriculture (CESCRA), \\ ICAR-Indian Agriculture Research Institute, ICAR-IARI, New Delhi-110012 \\ *Corresponding author e-mail: mjoydeep2k@yahoo.com
}

\begin{abstract}
Global climate change has a major impact on growth and sustainability of agro-ecosystem. Keeping in view the importance of rising $\mathrm{O}_{3}$ and $\mathrm{CO}_{2}$ concentration in atmosphere, a field experiment was conducted on chickpea (variety: Pusa 5023) in the experimental farm in Free Air Ozone and Carbon dioxide Enrichment (FAOCE) facility at ICAR-Indian Agricultural Research Institute (IARI), New Delhi under four ozone and carbon dioxide treatments (ECO: elevated $\mathrm{CO}_{2}(550 \pm 10 \mathrm{ppm})+$ elevated $\mathrm{O}_{3}(70 \pm 10 \mathrm{ppb})$; EC: elevated $\mathrm{CO}_{2}(550 \pm 10 \mathrm{ppm} \mathrm{ppm})+$ ambient $\mathrm{O}_{3}(30 \pm 10 \mathrm{ppb})$; EO: elevated $\mathrm{O}_{3}(70 \pm 10 \mathrm{ppb})+$ ambient $\mathrm{CO}_{2}(400 \pm 10 \mathrm{ppm})$ and $\mathrm{AMB}$; ambient $\mathrm{CO}_{2}(400 \pm 10 \mathrm{ppm})+$ ambient $\mathrm{O}_{3}(30 \pm 10 \mathrm{ppb})$ during rabi season of 2016-17. The results revealed that the plant height, above ground biomass, CGR and RGR and seed yield of chickpea was significantly highest in elevated $\mathrm{CO}_{2}(\mathrm{EC})$ treatment followed by ECO treatment and lowest in elevated $\mathrm{O}_{3}(\mathrm{EO})$ treatment. Elevated ozone had negative impact whereas elevated carbon dioxide had positive impact on growth, biomass and WUE of chickpea and when both are combined the negative impact of elevated ozone were counteracted by elevated carbon dioxide.
\end{abstract}

Keywords: Elevated $\mathrm{CO}_{2}$, elevated $\mathrm{O}_{3}$, RUE, CGR, RGR, chickpea

The impact of global climate change is rising concomitantly and is going to have a major impact on growth and sustainability of the agro ecosystems in the next hundred years. Understanding the effect of projected climatic conditions on crop growth and production in future is a major concern for worldwide food security programmes. The increase of greenhouse gases, like carbon dioxide $\left(\mathrm{CO}_{2}\right)$ and tropospheric ozone $\left(\mathrm{O}_{3}\right)$ are important factors affecting the global climate change (IPCC, 2014). The ozone with present concentration of $30 \mathrm{ppb}$ is considered as one of the most serious environmental stresses for agro ecosystems (Agathokleous et al., 2015). On the other hand, atmospheric carbon dioxide $\left(\mathrm{CO}_{2}\right)$ concentration is also increasing and has attained a level of nearly $402 \mathrm{ppm}$ during December 2015 (NOAA, 2016). Short term exposures of elevated $\mathrm{CO}_{2}$ the net photosynthesis is enhanced particularly for $\mathrm{C}_{3}$ plants resulting an increase in yield. Conversely, long-term elevated $\mathrm{CO}_{2}$ exposure results a reduction in growth due to photosynthetic acclimation. This process of photosynthetic "down-regulation" is mainly responsible for the reduction in metabolic activity due to reduced carboxylation as well as reduced amount of rubisco under enriched $\mathrm{CO}_{2}$ condition (Aranjuelo et al., 2009).
Chickpea (Cicer arietinumL.) a member of genus Cicer, tribe Cicereae, is third most important food legume of the world. Currently it is grown on about $11.5 \mathrm{~m}$ ha area out of which $96 \%$ of cultivation is in the developing countries. South and south east Asia contributes around $80 \%$ of global chickpea production out of which $83 \%$ is being produced by India with total production of 9.6 million tonnes (average of 2007-09 triennium) and its productivity is $850 \mathrm{~kg} \mathrm{ha}^{-1}$ India is the world's largest consumer of chickpea and it produces nearly $70 \%$ of all global production. There are very few studies, mostly on simulation analysis on effect of elevated $\mathrm{CO}_{2}$ on chickpea growth and yield (Srivastava et al. 2016; Saha et al. 2015). Keeping in view the importance of impact of elevated ozone and $\mathrm{CO}_{2}$ on crop, the present experiment was undertaken to study the combined impact of elevated ozone and $\mathrm{CO}_{2}$ on growth and WUE of chickpea.

\section{MATERIALAND METHODS}

\section{Experimental details}

A field experimentwas conducted on chickpea ( $C$. arietinum L.;cv. Pusa 5023-kabuli type) inside Free Air 


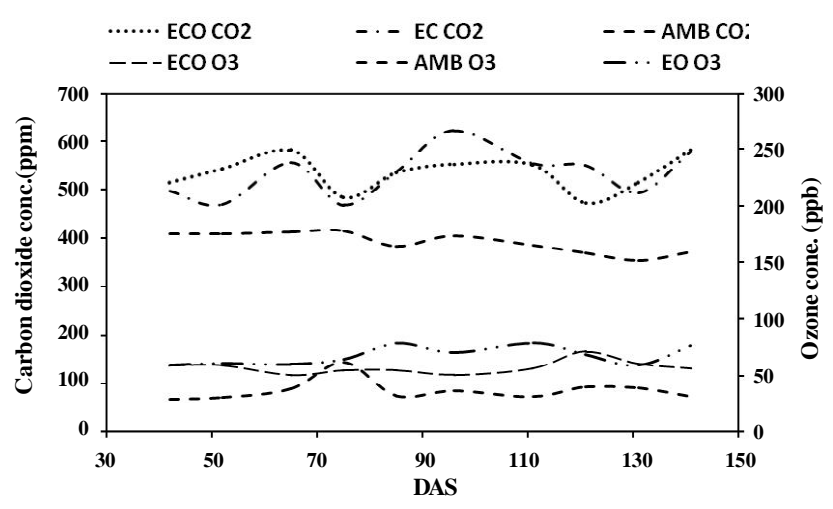

Fig 1: Variation in ozone and carbon dioxide concentrations over the growth period of the crop

Ozone and Carbon dioxide Enrichment (FAOCE) ring installed in experimental farm of ICAR-Indian Agricultural Research Institute (ICAR-IARI), New Delhi(2835' N latitude, $77^{\circ} 12^{\prime} \mathrm{E}$ longitude and at an altitude of $228.16 \mathrm{~m}$ above mean sea level). Crop was grown under elevated ozone, elevated carbon dioxide and in one ring crop was exposed to combination of both gases.

The experiment was laid out in CRD (factorial) with four replications. Elevated carbon dioxide (ECO: $550 \pm 10$ ppm), elevated ozone (EO: $70 \pm 10 \mathrm{ppb}$ ) and combination both gases (ECO: elevated carbon dioxide $(550 \pm 10 \mathrm{ppm})+$ elevated ozone $(70 \pm 10 \mathrm{ppb})$ ) was supplied in three different FAOCE rings (6m diameter), adjacent to these rings another ring was prepared where crop was grown without any external supply of ozone and carbon dioxide (AMB). The elevated concentrations were maintained inside the rings between $7.00 \mathrm{~h}$ to $18.00 \mathrm{~h}$ throughout the crop growth season starting from 40 days after sowing using high pressurized cylinders by an automatic monitoring system.Air was sampled automatically from the middle of each ring at canopy level and fed to an ozone and carbon dioxide analysers which measure the ozone concentrations. The sensors installed reads and maintains the elevated concentrations of elevated carbon dioxide and ozone (Fig. 1).

Foundation seeds of chickpea namely, Pusa-5023 (Kabuli type), were prepared treating the seeds with fungicide Captan@ $2 \mathrm{~g} \mathrm{~kg}^{-1}$ seed and then with Rhizobium @ $12 \mathrm{gkg}^{-1}$ seed and were sown on $16^{\text {th }}$ Nov, 2016 in well prepared soil of the FAOCE rings with a row to distance of $45 \mathrm{~cm}$ and plant to plant distance of $20 \mathrm{~cm}$. A basal dose of NPK@20:50:20 kg ha ${ }^{-1}$ was incorporated prior to sowing.

\section{Biometric observations}

Crop phenology was monitored twice in a week, by

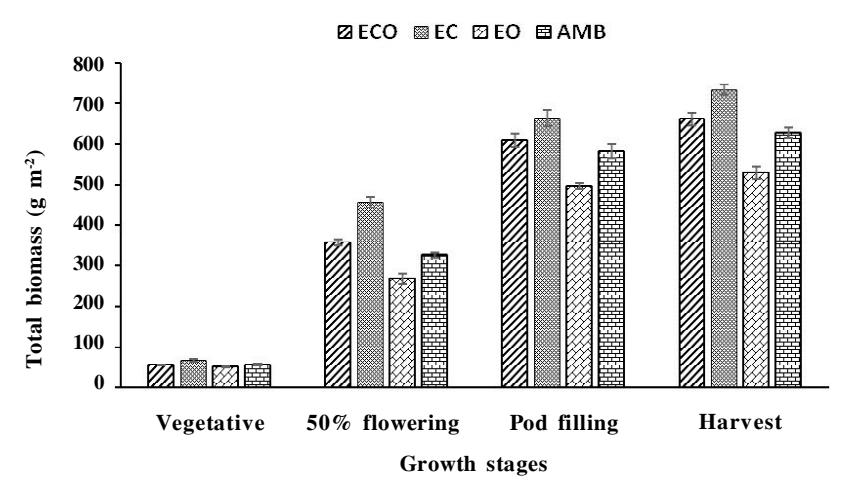

Fig 2: Total crop biomass production in chickpea leaves at different growth stages as influenced by different treatments of ozone and carbon dioxide.

observing the plants in the field and the following phenological events were observed: 50\% germination, flowering, pod development and physiological maturity. The plant height was measured from the ground level to the topmost portion of the plant with the help of meter scale at 10 days intervals. Plant biomass was measured from four plants randomly selected from each quadrant of the ring and the stem is cut at ground level. Plants were oven dried at $60^{\circ} \pm$ $5^{\circ} \mathrm{C}$ for 48 hours and weighed by using digital balance.

\section{Crop growth rate (CGR) and relative growth rate (RGR)}

Plant dry matter was calculated at different time interval using digital balance. Then CGR $\left(\mathrm{g} \mathrm{m}^{-2} \mathrm{day}^{-1}\right)$ was calculated for each treatment using the following formula;

$\mathrm{CGR}=\mathrm{W}_{2}-\mathrm{W}_{1} / \mathrm{SA}\left(\mathrm{t}_{2}-\mathrm{t}_{1}\right)$

where, $\mathrm{W}_{1}$ and $\mathrm{W}_{2}$ represents the total dry matter production ( $g$ ) at time $t_{1}$ and $t_{2}$, respectively and $S A$ is the land area occupied by plants at the time of sampling.

$R G R$ was calculated by using the following formula:

$\mathrm{RGR}=\left(\ln \mathrm{W}_{2}-\ln \mathrm{W}_{1)} /\left(\mathrm{t}_{2}-\mathrm{t}_{1}\right)\right.$

Water use efficiency (WUE) based on biomass of the crop was calculated from the regression between biomass and amount of water used ( $\mathrm{mm}$ ) whereas on yield basis it is calculated as amount of grain yield produced per mm of water used.

The statistical analysis was performed SAS version 9.2 software package.

\section{RESULTS AND DISCUSSION}

\section{Crop phenology}

In all the treatments germination of chickpea crop was 


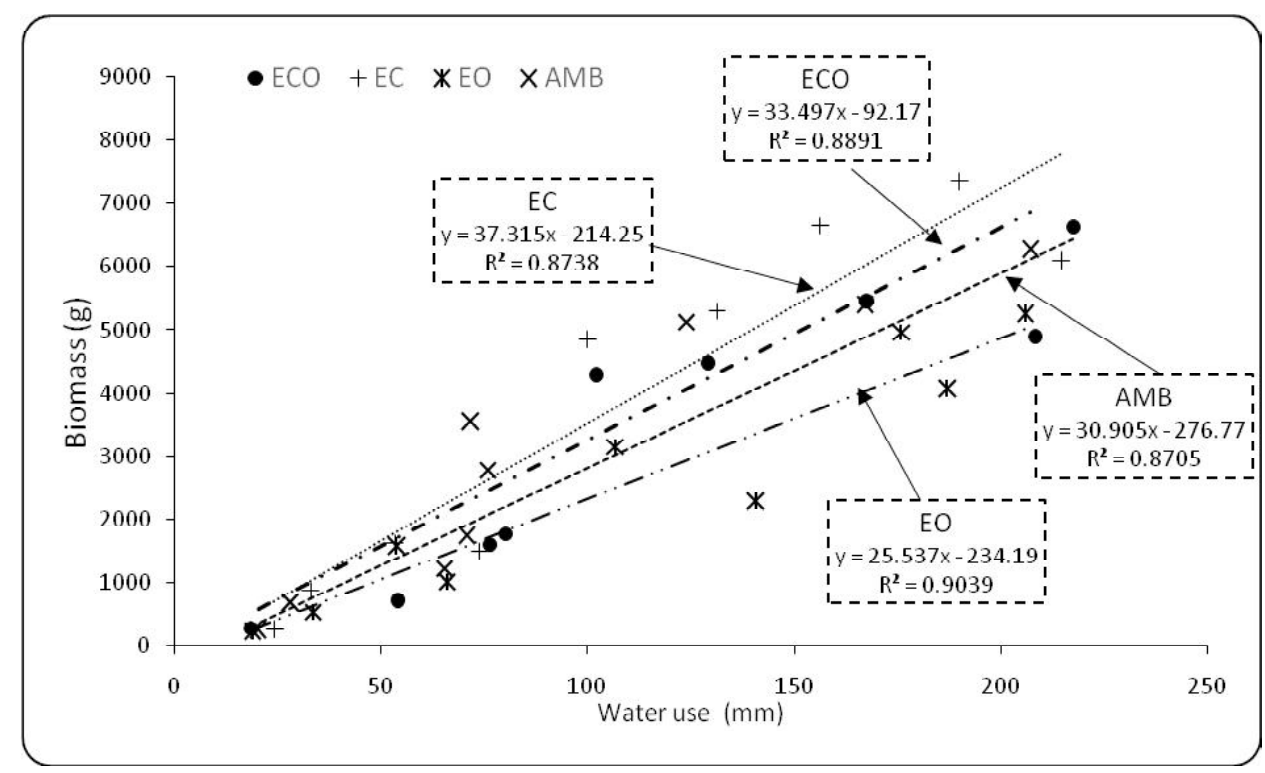

Fig 3: Biomass based water use of efficiency of chickpea crop under elevated surface ozone and carbon dioxide treatments

Table 1:Occurrence of phenological stages (in DAS) of chickpea crop as influenced by different treatments of ozone and carbon dioxide

\begin{tabular}{lcccc}
\hline Treatment & Germination & $50 \%$ Flowering & Pod initiation & Maturity \\
\hline EO & 7 & 85 & 113 & 131 \\
EC & 6 & 82 & 108 & 135 \\
ECO & 6 & 82 & 110 & 128 \\
AMB & 7 & 86 & 111 & 145 \\
\hline
\end{tabular}

Table 2:Temporal variation of plant height $(\mathrm{cm})$ in chickpea crop as influenced by different treatments of ozone and carbon dioxide

Treatments

Days after sowing (DAS)

\begin{tabular}{llllllll} 
& 52 & 65 & 75 & 85 & 96 & 121 & 131 \\
\hline ECO & 23.75 & $31.00^{\mathrm{B}}$ & $44.25^{\mathrm{AB}}$ & $47.75^{\mathrm{B}}$ & $63.00^{\mathrm{AB}}$ & $78.75^{\mathrm{AB}}$ & $93.00^{\mathrm{A}}$ \\
EC & 24.75 & $33.25^{\mathrm{A}}$ & $48.50^{\mathrm{A}}$ & $52.25^{\mathrm{A}}$ & $65.75^{\mathrm{A}}$ & $82.75^{\mathrm{A}}$ & $95.25^{\mathrm{A}}$ \\
EO & 22.25 & $26.75^{\mathrm{C}}$ & $37.75^{\mathrm{C}}$ & $42.50^{\mathrm{D}}$ & $59.25^{\mathrm{C}}$ & $68.38^{\mathrm{C}}$ & $71.50^{\mathrm{B}}$ \\
AMB & 23.25 & $29.25^{\mathrm{B}}$ & $41.00^{\mathrm{BC}}$ & $45.25^{\mathrm{C}}$ & $61.00^{\mathrm{BC}}$ & $72.13^{\mathrm{BC}}$ & $76.25^{\mathrm{B}}$ \\
CV $\%$ & 10.05 & 4.53 & 7.01 & 2.55 & 2.99 & 6.02 & 6.72 \\
LSD at 5\% & NS & 2.09 & 4.63 & 1.84 & 2.87 & 7.00 & 8.70 \\
\hline
\end{tabular}

observed in 6-7 DAS (Table 1). Initially, there was no variation in phenological stages, but it was visible after 42 DAS when treatments (elevated $\mathrm{CO}_{2}$ and $\mathrm{O}_{3}$ ) given inside the ring. The growth period shortened by about 10 days due to the elevated $\mathrm{CO}_{2}$ effect and 14 days due to elevated $\mathrm{O}_{3}$ treatment. Both elevated $\mathrm{CO}_{2}$ and elevated $\mathrm{O}_{3}$ advanced all phenological stages of the crop by different mechanism. Other researchers (Saha et al., 2015) also reported the early senescence in elevated $\mathrm{CO}_{2}$ treatment. Elevated $\mathrm{O}_{3}$ typically damage chlorophyll content of leaves and nutrient status thus enhance senescence of crops (Zhang et al., 2014).

\section{Plant height}

Plant height differed significantly due to treatments (Table 2). The highest plant height $(95.2 \mathrm{~cm})$ was observed in EC at 131 DAS followed by $93.0 \mathrm{~cm}$ in ECO, $76.25 \mathrm{~cm}$ in AMB, $71.5 \mathrm{~cm}$ in EO treatments. Plant height was significantly higher under elevated $\mathrm{CO}_{2}$ condition than elevated $\mathrm{O}_{3}$ and their interaction. The effect was more prominent at $65 \mathrm{DAS}$ and $85 \mathrm{DAS}$ which was coinciding with 
Table 3: Crop growth rate $\left(\mathrm{g} \mathrm{m}^{-2} \mathrm{day}^{-1}\right)$ and relative growth rate $\left(\mathrm{mg} \mathrm{g}^{-1}\right.$ day $\left.^{-1}\right)$ of chickpea crop as influenced by different treatments of ozone and carbon dioxide

\begin{tabular}{|c|c|c|c|c|c|c|c|c|}
\hline \multirow[t]{3}{*}{ Treatments } & \multicolumn{8}{|c|}{ Days after sowing (DAS) } \\
\hline & \multicolumn{2}{|c|}{$30-60$} & \multicolumn{2}{|c|}{$60-90$} & \multicolumn{2}{|c|}{$90-120$} & \multicolumn{2}{|c|}{$120-141$} \\
\hline & CGR & RGR & CGR & RGR & CGR & RGR & CGR & RGR \\
\hline ECO & $2.42^{\mathrm{B}}$ & $216.25^{\mathrm{B}}$ & $6.23^{\mathrm{B}}$ & $328.50^{\mathrm{B}}$ & $6.94^{\mathrm{B}}$ & $388.50^{\mathrm{B}}$ & $5.49^{\mathrm{B}}$ & $291.25^{\mathrm{B}}$ \\
\hline $\mathrm{EC}$ & $3.54^{\mathrm{A}}$ & $288.25^{\mathrm{A}}$ & $7.50^{\mathrm{A}}$ & $396.50^{\mathrm{A}}$ & $8.30^{\mathrm{A}}$ & $443.50^{\mathrm{A}}$ & $6.34^{\mathrm{A}}$ & $356.25^{\mathrm{A}}$ \\
\hline EO & $2.01^{\mathrm{B}}$ & $152.75^{\mathrm{C}}$ & $4.36^{\mathrm{D}}$ & $268.75^{\mathrm{C}}$ & $5.36^{\mathrm{C}}$ & $312.00^{\mathrm{C}}$ & $4.37^{\mathrm{D}}$ & $206.50^{\mathrm{D}}$ \\
\hline AMB & $2.40^{\mathrm{B}}$ & $187.50^{\mathrm{B}}$ & $5.65^{\mathrm{C}}$ & $326.00^{\mathrm{B}}$ & $6.69^{\mathrm{B}}$ & $359.50^{\mathrm{B}}$ & $4.97^{\mathrm{C}}$ & $252.00^{\mathrm{C}}$ \\
\hline $\mathrm{CV} \%$ & 10.29 & 10.14 & 5.87 & 7.22 & 3.84 & 6.45 & 5.40 & 7.02 \\
\hline LSD at $5 \%$ & 0.41 & 33.00 & 0.53 & 36.70 & 0.40 & 37.33 & 0.44 & 29.92 \\
\hline
\end{tabular}

Table 4:Yield water use of efficiency (WUE) of chickpea crop under elevated surface ozone and carbon dioxide treatments

\begin{tabular}{lccc}
\hline Treatments & $\begin{array}{c}\text { Seed yield } \\
\left(\mathrm{gm}^{-2}\right)\end{array}$ & $\begin{array}{c}\text { Water use } \\
(\mathrm{mm})\end{array}$ & $\begin{array}{c}\text { WUE } \\
\left(\mathrm{kg} \mathrm{ha}-\mathrm{mm}^{-1}\right)\end{array}$ \\
\hline ECO & $270.40^{\mathrm{B}}$ & $217.50^{\mathrm{A}}$ & $12.46^{\mathrm{B}}$ \\
EC & $324.33^{\mathrm{A}}$ & $190.03^{\mathrm{C}}$ & $17.07^{\mathrm{A}}$ \\
EO & $191.50^{\mathrm{C}}$ & $206.98^{\mathrm{B}}$ & $9.26^{\mathrm{C}}$ \\
AMB & $245.88^{\mathrm{B}}$ & $207.30^{\mathrm{B}}$ & $11.86^{\mathrm{B}}$ \\
CV\% & 8.56 & 2.48 & 9.29 \\
LSD at 5\% & 34.04 & 7.84 & 1.81 \\
\hline
\end{tabular}

$50 \%$ flowering and pod filling stage. The plant height at harvest was more in EC treatment than in ECO (combined treatment) which was due to positive effect of $\mathrm{CO}_{2}$ fertilization and negative effect of $\mathrm{O}_{3}$ on plant growth.

As chickpea is a leguminous crop with nitrogen fixing nodules, more nodulation is possible under elevated $\mathrm{CO}_{2}$ condition to support the mechanism of growth enhancement (Gamper et al., 2005). The entry of ozone through stomata reduces the growth rate due the disruption of cellular process (Bhatia et al., 2013).

\section{Biomass accumulation}

The accumulated biomass was highest under elevated $\mathrm{CO}_{2}$ condition in comparison to all other treatments (Fig.2) at all the growth stages.Biomass accumulation in ECO and AMB treatments were statistically at par. The lowest biomass accumulation reduction was observed in $\mathrm{EO}$ treatment. The increase of above ground biomass accumulation is due to more photosynthates partitioned towards above ground parts by $\mathrm{CO}_{2}$ enriched crop. Reduction of stomatal aperture also decrease the entry of $\mathrm{O}_{3}$ inside leaves in elevated $\mathrm{CO}_{2}$ treatment which is a detoxifying process of $\mathrm{O}_{3}$ and ultimately increase the availability of substrates (Pearson et al., 1995).

\section{CGR and RGR}

The highest CGR and RGR was observed in EC treatment, followed by ECO and AMB treatments and the lowest in EO treatment (Table 3). Among all the treatments highest CGR and RGR was observed during 90-120 DAS after that it decreased. Both CGR and RGR significantly increased under elevated $\mathrm{CO}_{2}$ and in combination treatments but significantly decreased under elevated $\mathrm{O}_{3}$ treatment. Elevated $\mathrm{CO}_{2}$ treatment recorded an increase of 24.0 to $47.5 \%$ in CGR and 21.6 to $53.7 \%$ in RGR over ambient condition respectively.

\section{Water use efficiency (WUE)}

Water use efficiency on account of biomass accumulation significantly differed dute to different $\mathrm{CO}_{2}$ and $\mathrm{O}_{3}$ treatments (Fig .3). Total water use was $217.5 \mathrm{~mm}$ and $206.9 \mathrm{~mm}$ for ECO and EO, respectively which was significantly higher than EC (190.0 mm) and AMB (207.3 $\mathrm{mm}$ ) treatments. Whereas the WUE was significantly higher under EC ( $37.32 \mathrm{~kg}$ ha- $\left.\mathrm{mm}^{-1}\right)$ than other treatments. Similar trend was also observed in WUE on seed yield basis (Table 4). The WUE for yield was significantly lower under EO $\left(9.26 \mathrm{~kg} \mathrm{ha}-\mathrm{mm}^{-1}\right)$ in comparison to other treatments. It was 


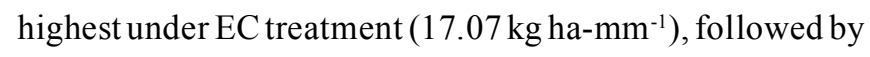

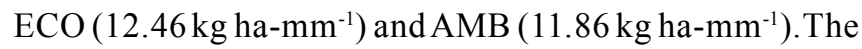
reduction of WUE was due reduction of yield and biomass under elevated $\mathrm{O}_{3}$ as compared to crop exposed to elevated $\mathrm{CO}_{2}$ and ambient condition.

\section{CONCLUSION}

Elevated ozone has negative impact whereas elevated carbon dioxide has positive impact on growth, biomass and WUE of chickpea and when both are combined the negative impact of elevated ozone were counteracted by elevated carbon dioxide. WUE was significantly increased in EC and reduced in EO, ECO values are higher than AMB. During crop growing season both CGR and RGR was significantly increased under elevated $\mathrm{CO}_{2}$ and in combination treatments but significantly decreased under elevated $\mathrm{O}_{3}$ treatment.

\section{REFERENCES}

Agathokleous, E., Saitanis, C. J., and Koike, T. (2015). Tropospheric $\mathrm{O}_{3}$, the nightmare of wild plants: a review study. J. Agric.Meteorol., 71(2), 142-152

Aranjuelo, I., Pardo, A., Biel, C., SavE, R.,AZCÓN BIETO, J. O. A. Q. U. I. M., and NoguES, S. (2009). Leaf carbon management in slow growing plants exposed to elevated CO2. Global Change Biol., 15(1), 97-109.

Bhatia,A., Kumar, V., Kumar,A., Tomer, R., Singh, B., and Singh, S. (2013). Effect of elevated ozone and carbon dioxide interaction on growth and yield of maize. Maydica, 58(34), 291-298.
Gamper, H., Hartwig, U. A., and Leuchtmann, A. (2005). Mycorrhizas improve nitrogen nutrition of Trifoliumrepens after 8 yr of selection under elevated atmospheric $\mathrm{CO} 2$ partial pressure. New Phytologist, 167(2), 531-542.

IPCC (2014). Climate Change 2014-Impacts, Adaptation and Vulnerability: Regional Aspects. Cambridge University Press.

NOAA (2016). Trends in atmospheric carbon dioxide. http:// www.esrl.noaa.gov/gmd/ccgg/trends/\#mlo_growth, Accessed on January 18, 2017.

Pearson, M. (1995). Effects of ozone on growth and gas exchange of Eucalyptus globulus seedlings. Tree physiology, 15(3), 207-210.

Saha, S., Sehgal, V. K., Chakraborty, D., and Pal, M. (2015). Atmospheric carbon dioxide enrichment induced modifications in canopy radiation utilization, growth and yield of chickpea [Cicer arietinum L.)]. Agric. Forest Meteorol., 202, 102-111.

Srivastava,A.K., Silawat, S. andAgrawal, K.K.(2016). Simulating the impact of climate change on chickpea yield under rainfed and irrigated conditions in Madhya Pradesh. $J$. Agrometeorol., 18(1):100-105.

Zhang, W., Wang, G., Liu, X., and Feng, Z. (2014). Effects of elevated $\mathrm{O}_{3}$ exposure on seed yield, $\mathrm{N}$ concentration and photosynthesis of nine soybean cultivars (Glycine $\max ($ L.) Merr.) in Northeast China. Plant Sci., 226, 172-181. 